\title{
THE INFLUENCE OF POWER POINT PRESENTATION TO IMPROVE STUDENTS' READING SKILL OF SENIOR HIGH SCHOOL
}

\author{
Margareth Teacher ${ }^{1 *}$, Andrian Petrus Sirait ${ }^{2}$, Oloan Petrus Siahaan ${ }^{3}$, Dapot Harianja ${ }^{4}$ \\ ${ }^{1,2,3,4}$ University of HKBP Nommensen Pematangsiantar \\ E-mail: ${ }^{1)}$ margarethtea25@gmail.com
}

\begin{abstract}
This research was made to find out the influence of power point presentation in improving students' reading skill. Beside that, this research has aim to find out the factors that influences the students' reading skills improvement of narrative text. The researchers used classroom action research as the method of this research. The researchers also used test as an instrument by reading text in the power point presentation. From the result of the research, it shows that the students' scores in reading text increasing. There is a major that influenced their improvement, which is the choice of material. The material should be new and relevant with the students' imagination. Thus, they became interested in reading the text from the power point presentation
\end{abstract}

Keywords: Power point, Reading Skill, Students

\section{INTRODUCTION}

English is a language that has an important role in the development of technology and science. This is caused by the role of English as an introductory language for communication media globally. In the field of education, students must be able to control four skills in English, namely reading, listening, writing, and speaking. The four skills cannot be separated, and must be studied side by side.

To achieve success in learning English, students must be able to control the four skills, including reading skills. Reading is an intermediary skill in learning English, which means that every aspect of learning languages, reading plays the biggest role.

In Graduate Competency Standard (SKL) in BSNP (Badan Standar Nasional Pendidikan, 2006), it is stated that every student must be able to read in English, and be able to understand what they read in English, such as general and specific information, and the meaning of the words.

At the high school level, on grade $10^{\text {th }}$, in English subject, there are three types of text studied by the students, namely descriptive text, recount text, and narrative text. In this research, researchers used narrative text to teach reading for the students using the classroom action research method.

Before conducting the classroom action research, the researchers done an observation during teaching reading skill on the grade $\mathrm{X}$ class X MIA 1 in SMA Kampus FKIP Pematangsiantar. The researchers observed the teacher's manner in teaching and also the students' progress in the learning process. 
From the observation, researchers found that the students still could not read well, especially in reading narrative text. They still have difficulties to identify some words and the main idea of the text, and then they still could not analyze the information of the text because of the limitation of their vocabularies.

Besides that, from the observation, we found that the text given was in the form of worksheet from textbook, so that the text was not colorful and there was no illustration to describe the situation of the narrative text. Thus, it was difficult for the students to build their comprehension in their mind.

There were several reasons why the teacher used the worksheet from textbook as the media. First, the worksheet from textbook has been concluded the core of the narrative text material, so that the teacher easy to deliver the explanation. Second, the worksheet had provided task, so that the students could directly do the exercise after reading the text and got explanation from the teacher.

Based on this observation, the researchers found several problems that hinder students in mastering reading skill. Thus, it is important for the teacher to use a media to help the teacher in teaching reading, also to make the students more interested in the learning process.

Therefore, it can be concluded that a media is needed to solve the problems of teaching and learning reading. One of a good media that can be used for teaching reading is by using power point presentation. Power point presentation is a good media that can be used in teaching reading.

Several reasons that support the use of power point in teaching reading are (1) the material of the text in power point can use pictures, and symbols that makes the presentation more attractive; (2) the color and animated pictures of the text by using power point presentation can activate the students' interests, and make them more active in participating in the learning process. From these reasons, it can be concluded that power point presentation can help the teacher in delivering the lesson, and can help the students in understanding the lesson.

Thus, by designing the interesting material, enjoyable activity during learning reading by using slides of power point presentation can support the improvement of reading skills of the students.

\section{REVIEW OF LITERATURE}

\subsection{Reading Skill}

Reading is a process when readers learn something, so they get information about what they read (Grabe, 2009). In learning process, some teachers generally used book as the media of teaching reading, and the teachers also asked the students in reading a text to get information abou what they have read.

According to Weaver (2009), 'reading is a process which is very much determined by what the reader's brain and emotions and beliefs bring to the reading: the knowledge/information (or misinformation, absence of information), strategies for processing text, moods, fears and joys - all of it". In addition, Turner (1998) stated that reading is the effort of getting meaning or message that delivered by the writer to the reader. 
Based on the definitions, it can be concluded that reading is a process that involved the reader and the passage. During the process of reading, the reader will try to get message and to get information based on what she/he read, then the reader's insight and knowledge will increase.

\subsection{Narrative Text}

Narrative text is a text that tells a story of past event, that contains of fiction and fantasy, and aims to entertain the readers. Therefore, the generic structure of narrative text are as follows:

1. Orientation

Orientation is the first part of narrative text that introduces the topic or the story of the text.

2. Complication

Complication is the second part of narrative text that describes problems of the story. It can also called as the climax.

3. Resolution

Resolution is the third part of narrative text that tells the solution in solving the climax of the story.

4. Coda

Coda is the last part of narrative text that tells the message or the moral lesson contains in the story for the readers.

Then, several language features of narrative text are 1) using processes verbs, 2) using temporal conjunction, 3) using simple past tense, and 4) using subjective pronoun.

\subsection{Power Point Presentation}

Ayer (2011) stated that power point is a type of presentation that allows one to show color texts and image with simple animation and sounds. This tool can be shown on a computer screen or using a projector with a large screen for the whole class who can view the same presentation at the same time.

In addition, Ardiantoni (2011) stated that power point has many features which make it useful classroom tool. It means that the teachers can use power point to manage the time in giving explanations for the material to the students, and the teacher also can use the power point in unlimited time, because power point is a digital platform that can remain forever.

Rusman (2012) added that power point presentation is a good application in presenting teaching material such as texts, graph, voice, video, and animation.

Based on the definitions above, it can be concluded that power point presentation is a good media in teaching learning process. 


\section{RESEARCH METHOD}

The researchers used classroom action research as the method of this research. Classroom action research is a method that applied in teaching, and aims to to see the students' improvement after the implementation of media in the teaching learning process.

Classroom action research is research conducted in the classroom using an action to improve the quality of the teaching and learning process in order to obtain better results than before. Classroom action research takes several cycles because the teacher has to implement the method or media to achieve the desired results.

Therefore, for this research, researchers conducted two cycles. In one cycle, there are four steps, such as planning, acting, observation, and reflection (Arikunto, 2013). Improvement the problem in this research is brought about by the series of cycle.

The subject of this research is the students of grade X MIA 1 in SMA Kampus FKIP Pematangsiantar, which consist of 18 students.

\section{FINDINGS AND DISCUSSION}

The researchers done two cycles in this classroom action research. Based on the application of power point presentation that the researchers had conducted in the first and second cycle, the researchers found that power point presentation had influence to improve the students' reading skill of narrative text. The application of power point presentation was able to make the students more active in the learning process, and made them interested in learning in the classroom.

The minimum score that students have to achieve is 76 according to KKM of the school. And the indicator of the success of this classroom action research is that $75 \%$ of students achieved the minimum score.

This improvement was proved by the result of the students' total score of reading of narrative text titled "Malin Kundang". In the first cycle, about 7 students achieved good mark, and then 11 students not achieved the good mark. It means that about seven students have good reading skill in reading narrative text, and about eleven students have bad reading skill in reading narrative text. Thus, $39 \%$ of students achieved the minimum score. It can be concluded that this first cycle is not succeeded yet. Therefore, the next cycle is needed to measure the improvement.

For the second cycle, 4 students achieved bad score, and then 14 students achieved good score. It means that about four students still difficult in reading, and about fourteen students have good reading skill in reading narrative text. Thus, $77 \%$ of students achieved the minimum score and beyond. It can be concluded, that there is changes of the percentage of the first cycle and the second cycle. The percentage increase about $38 \%$ from the first cycle towards the second cycle. It means that the use of power point presentation influence the students abilities in reading.

Based on these findings and discussion, researchers can conclude that power point presentation is a good media that can be used to improve students reading skill, in order to help them learning others skill of English. Power point is also a good media that can be used as a strategy in teaching by the teacher to teach reading to the students. 


\section{JOURNAL OF HUMANITIES, SOCIAL SCIENCES AND BUSINESS (JHSSB) \\ VOLUME 1 ISSUE 2 (2022)}

\section{CONCLUSION}

The researchers found that the use of power point presentation can increase the students' reading skill of reading narrative text after conducted the two cycles in the classroom. This improvement was influenced by several factors, such as material, media, teaching strategy, and the teacher's approach.

The firs factor is material. The material of reading narrative text should be new, various and creative. The second factor is media. Nowadays, computer or laptop has become the daily need of human life. Thus, this tool can help the teacher deliver the explanation. Moreover, the material of narrative text will become easier to be understood by showing them in the slide of power point presentation.

The third factor is teaching strategy. Teaching strategy is the teacher's action in implementing teaching plans, in order to influence students to achieve the established goals. By using the appropriate teaching strategy, students will be interested in following the learning process.

The fourth factor is teacher's approach. It is important to recognize the students' characteristic before teaching reading in the class. This approach can help the teacher delivering the instruction.

Based on the factors above, if they all well prepared, they will affect students' motivation and interest in learning. It has been proven, that by using interesting materials and media such as text in power point presentation, and by using good teaching strategies, students will be motivated to participate in the learning process.

Based on the application of the power point presentation media that has been conducted by researchers for two cycles, researchers found that power point can be used to improve students' reading skills, besides that, it can also increase students interests so that they become more concentrated during the learning process.

\section{REFERENCES}

Ardiantoni. (2011). Pengaruh Media Power Point dalam Meningkatkan Kemampuan Berbicara Bahasa Inggris (studi eksperimen) di SMP Negeri 2 Koto Baru Dharmasraya. Thesis. Padang: UNP

Arikunto, S. (2013). Prosedur penelitian suatu pendekatan praktik. Jakarta: PT. Rineka Cipta

Ayers, Susan. (2011). Definition of Microsoft Power Point. Retrieved on February $7^{\text {th }}$, 2022 from : $\quad$ http://presentationsoft.about.com/od/powerpointtipsan dfaqs/f/ppt_overview.htm

Badan Standar Nasional Pendidikan. (2006). Standar Isi. Badan Standar Nasional Pendidikan: Jakarta

Grabe, W. (2009). Reading a Second Language Moving from Theory to Practice. New York Cambridge University Press

Rusman. (2012). Model - Model Pembelajaran. Depok : PT Rajagrafindo Persada

Turner, T. N. (1998). Teaching Reading Comprehension for Meaning. Los Angeles: Scott, Foreman and Company 
Weaver, Constance. (2009). Reading Process: Brief Edition of Reeading Process and Practice. Ohio: Miami University, Oxford 